\title{
- CONTRATO de cONCESSÃO DE VENDA COM EXCLUSIVIDADE (CONCESSÃO COMERCIAL)
}

\author{
RUBENS REQUIÃO \\ Professor Catedrático de Direito Comercial da Fa- \\ culdade de Direito da Universidade Federal do \\ Paraná.
}

SUMÁRIO: 1 - A capacidade criativa do direito comercial. 2 - Fundamentos econômicos do contrato de concessão comercial. 3 - Conceito e objeto do contrato. 4 - Natureza jurídica da concessão comercial. 5 - Qualificação do contrato de concessão comercial. 6 - Atipicidade do contrato. 7 - Distinção em relação aos contratos afins. 8 - A clausula de exclusividade. 9 - A clausula de exclusividade e a recusa de venda. $10-$ A concessão comercial no direito comparado (Estados Unidos e Bélgica). 11 - A concessão comercial na América Latina (S. Domingos, Panamá, Honduras, S. Salvador, Argentina). 12 Rescisão do contrato e a indenização. 13 Ruptura do contrato a prazo determinado. 14 O tema em face das leis brasileiras. 15 - Rescisão do conirato atípico no direito brasileiro.

1 - A capacidade criativa do direito comercial. O grande atrativo que o direito comercial exerce sobre o nosso espírito, de modo a torná-lo a disciplina jurídica de nossa predileção, é a sua capacidade de ser um real e efeito instrumento do progresso. E ao referirmo-nos a progresso aludimos à expressão em seu amplo significado, não só de instrumento renovador da ciência jurídica, mas também de valioso promotor da civilização.

Desde a Idade Média, quando o direito comercial surgiu como um conjunto de regras técnicas e jurídicas para a defesa do crédito e do tráfico mercantil, tão combalidos pelas dilações e anistia que

* Conferência proferida a 12 de março de 1972, no Instituto dos Advogados, no Rio de Janeiro, inaugurando o Curso de Direito Comercial organizado por aquela entidade. 
a demagogia constantemente concedia aos devedores relapsos, na decadência romana, o direito comercial se caracteriza pelo informalismo de suas regras, contrapondo-se nesse particular, ao estilo solene do direito civil. Esse informalismo necessário à instantaneidade e velocidade das operações em massa, permitiu e incentivou o gênio inventivo dos empresários, sua capacidade de adaptar arcaicas instituições aos seus propósitos lucrativos, permitindo ao nascente direito uma flexibilidade e um dinamismo que o tornaram capaz de fornecer às empresas o instrumental técnico e jurídico essencial ao seu desenvolvimento. Essa criatividade não se limitou ao período inaugural da autonomia do direito comercial, mas se projetou nos séculos posteriores, permanecendo até aos nossos dias.

Essa plasticidade do direito comercial, com efeito, permitiu que ele se assenhoreasse de muitos institutos de direito das gentes ou do primirivivo direito marírimo, para pô-los a serviço do comércio terrestre, como hoje se permite emprestar normas de outros ramos de direito para amoldá-los ao sistema que tutela. $O$ nauticum foenus deu nascimento ao seguro marítimo, posteriormente desdobrado em vários ramos adaptáveis as conveniências do tráfico mercantil; o contrato de commenda inspirou a formação das sociedades em comandiła simples. E no fim da Idade Média o direito comercial, lentamente, começou a se apropriar de uma instituição que fôra imaginada para atender aos interesses administrativos do Estado. Com efeito, todos sabem que as sociedades por ações surgiram para atender aos objetivos colonialistas da política mercantilista dos príncipes. Eram constituídas por carta real, ato essencialmente político, que impunha a aliança entre investimentos e interesses públicos e capitais privados. O capitalismo empresarial do século XIX, em pleno fastígio do liberalismo econômico, $f \in z$ reverter essa instituição do direito público para o direito privado, libertando a sociedade anônima da tutela do Estado, permitindo assim que se tornasse o mais formidável instrumento do progresso econômico dos últimos tempos.

Todas essas reminiscências nos vêm ao espírito quanđo nos dedicamos à pesquisa de uma nova instituição mercantil, desta vez criada em pleno século $X X$, e que no momento se torna alvo de avançados estudos em várias partes do mundo. Referimo-nos ao contrato de concessão de venda com exclusividade, também denominado simplesmente de contraío de concessão comercial. O mesmo genio de adaptação, seguido de pronta capacidade construtiva, apanágio do direito comercial, permitiu que as grandes empresas industriais, nos dias que passam, emprestassem ao direito público administrativo uma de suas 
peculiares instituições - a concessão de serviço público - para colocá-la, devidamente ajustada, ao serviço das empresas modernas.

2 - Fundamentos econômicos do contrato. Antes de abordarmos - estudo técnico-jurídico do contrato de concessão de venda com exclusividade, devemos, como é de bom tom, tecer algumas consideræções sobre o seu conteúdo.

Observando agudamente que as empresas modernas, de dimensões gigantes, em si e por si mesmas representam importantes fatores de poder, e que de um modo geral o direito norte-americano, quando não a própria economia americana, impedem o monopólio, - eminente Professor da Universidade de Columbia ADOLF A. BERLE JR. registra que duas ou tres delas, no máximo cinco empresas, dominavam mais da metade do mercado dos Estados Unidos, em 1945, isto é, época em que escrevia a obra "A Revolução Capitalista do Século XX". Particularizando o tema que nos envolve, demonstra que as grandes empresas ultrapassam a simples aritmética dos bens realmente de sua propriedade, no sentido de projetar-se sobre o controle de propriedade alheia. E o que enseja esse curioso e grave fenômeno, diz ele, é a concessão de venda com exclusividade.

Vale ouvir a lição do eminente professor BERLE JR.: "O impacto exercido por muitas empresas, escreve ele, - a General Motors, por exemplo, ou as grandes companhias de petróleo - ultrapassam de muito os respectivos limites patrimoniais. Existem, por exemplo, em estimativa sumária, cerca de tres bilhões de dólares invertidos em garagens e instalações de serviço de propriedade dos chamados "pequenos" empresários, com contratos de agência firmados com os principais fabricantes de automóveis. Os donos são pequenos empresários independentes, que, embora rotulados de corporation, não são evidentemente nenhumas grandes empresas. Nominalmente são independentes. Mas as suas normas de procedimento, seus métodos de operação, em grande parte os seus preços, são estabelecidos pe!as companhias cujos carros vendem. O mesmo procede quanto ao "pequeno comerciante" que é "dono de um posto de abastecimento de gasolina". A faculdade de que dispõe uma grande empresa, quanto a decidir e dirigir operações, transcende às limitações do exercício normal do direito de propriedade. $O$ seu poder se projeta além do alcance real de sua empresa - na verdade, - vai muito mais longe, embora uma estatística quanto à extensão do âmbito dessa influência ainda não exista" (ob. cit. pg. 27).

Numa pincelada apenas o mestre norte-americano revela toda a extensão sociológica, econômica e jurídica que o tema sugere, como 
um dos eficientes instrumentos do atual estágio do capitalismo empresarial. E tal é a importância e gravidade dos problemas que a concessão de venda com exclusividade gera, que o Congresso dc*s Estados Unidos promulgou lei federal sobre concessão de comércio de automóveis, que pretendemos analisar na devida oportunidade.

Por outro lado, RENÉ SAVATIER, na França, estudando as transformações econômicas e sociais do direito civil em nossos dias, registra curiosas consequências e reflexos que o intervencionismo estatal acarreta, criando e admitindo monopólios privados, em cuja esteira se aproveitam as empresas comerciais. Partindo da pesquisa da "gênese de monopólios contratuais", aborda o Professor SAVATIER a noção de exclusividade, instrumento jurídico de consequência monopolística, cuja aplicação técnica nas negociações comerciais permite muitas vezes que ela se integre num patrimônio privado, valorizando as empresas privilegiadas. SAVATIER, assim, nela vê um monopólio, seja de compra, seja de venda ou de representação comercial (Las Metamorphoses Économiques et Socieales du Droit D'Aujourd'hui, Vol. I, pg. 373, n. $^{\circ} 310$, ter.).

Se confrontarmos as conclusões de BERLE JOR., e de SAVATIER, a respeito da concessão de venda com exclusividade, percebemos que ambos tiram ilações diferentes das consequências desse moderno negócio jurídico. Enquanto BERLE JOR. se preocupa com a projeção de poder da empresa concedente sobre a propriedade do concessionário, por via da própria estrutura econômica do negócio que sujeita de certa forma, uma ao poder da outra, SAVATIER se impressiona particularmente com a valorização patrimonial da empresa privilegiada com o monopólio privado. Com efeito, o famoso Professor Poitiers registra que a "técnica das negociações comerciais faz muitas vezes entrar, num patrimônio privado, o que se chama "exclusividades". Estas são bens geralmente negociáveis, ainda que sua transmissão contratual ou sucessória não seja sempre admitida, seja nos costumes, seja para os viajantes e representantes de comércio, na lei. Mas os agentes comerciais, os concessionários, os agentes de seguro, muitos fornecedores ou compradores profissionais são admitidos, por nosso direito, a obter exclusividade que valorizam sua empresa em geral, que tornam cessíveis com esta última, e, algumas vezes, são admitidos a negociá-la separadamente (ob. cit.).

Ressaltamos essas opiniões tão divergentes sobre os efeitos econômicos e patrimoniais da concessão comercial para, de início, projetar a complexidade da nova categoria de negócio jurídico. Mas, analisando melhor as duas valiosas opiniões de tão eminentes mes- 
tres, que pontificam em sociedades distintas, determinadas por sistemas jurídicos diversos, podemos chegar à conclusão de que os dois efeitos, por ambos os juristas ressaltados, podem se ajustar ao invés de se repelirem. Se é verdade que a concedente projeta o seu poder além do alcance real de sua empresa, sobre outra que a ela por conveniência se sujeita, não menos verdade é que a empresa subordinada economicamente, mantendo sua integridade jurídica, obtem da exclusividade inerente à concessão de venda, uma objetiva valorização patrimonial.

3 - Conceito e objetivo do contrato. O contrato de concessão de venda com exclusividade constitui, sem dúvida, uma nova técnica de comercialização, de organização do mercado distribuidor de produtos industrializados ou de alta-tecnicidade, de que tanto falam os autores europeus. Através desse sistema, a empresa comercial se relaciona com a empresa industrial, de forma a manter, cada uma, a integridade de sua personalidade jurídica. Nesse sistema de comercialização, a empresa produtora, tal como o Estado no contrato de concessão de serviço público, descentraliza sua atuação, deferindo a outra empresa estranha a distribuição e colocação de seus produtos no mercado consumidor. Dessa forma, a empresa produtora, organizando e disciplinando a rede de concessionários, não se preocupa com o escoamento de sua produção, descentralizando o setor comercial que é complementar da atividade produtiva. A empresa industrial se restringe a vender em grosso os seus produtos para concessionários - que irão revendê-los, ao rełalho, sob o seu conirole técnico e sob sua estreita vigilância.

O Professor HOUIN, ao prefaciar a difundida monografia ao Professor JEAN GUYÉNOT, da Faculdade de Direito de Paris, intitulada "Les Contrats de Concession Commerciale", explica que o contrato de concessão de venda com exclusividade corresponde a um estado da Economia no qual o produtor necessita deixar o cuidado da comercialização de seus produtos a especialistas na distribuição, mas ligando essas empresas à sua por cláusulas convencionais, tais como as cláusulas de exclusividade.

Em fase das noções econômicas preliminares aqui apresentadas, podemos nos preocupar, como introdução à pesquisa da nova categoria jurídica negocial, com a sua definição. A definição proposta pelo Professor CHAMPAUD, da Faculdade de Direito de Rennes, tem sido por muitos aceita, inclusive pelos autores BUISSON, LAGGER e TANDEAU DE MARSAC, que a consideram em França a mais completa. Definiu o Professor CHAMPAUD o contrato de concessão comer- 
cial "como uma convenção pela qual um comerciante, chamado concessionário, coloca sua empresa de distribuição ao serviço de um comerciante ou industrial chamado concedente, para assegurar, exclusivamente, sobre um território determinado, durante um período limitado e sob a fiscalização do concedente, a distribuição de produtos cujo monopólio de revenda lhe é concedido (La Concession Commerciale, Revue Trimestrielle de Droit Commercial, 1963, pg. 471, n. $\left.{ }^{\circ} 24\right)$.

Menos complexa e explícita é a definição apresentada pelo Professor GUYÉNOT, de que "em termos simples, a concessão comercial implica a atribuição de um monopólio de exclusividade de venda a comerciantes escolhidos pelo produtor para fazê-los participar de um sistema de comercialização de seus produtos' (Ob. cit., pg. 25, n. $\left.{ }^{\circ} 15\right)$.

No notável estudo sobre a. "Nałura Giuridica della Compravendita con Exclusiva" o. Professor REMO FRANCESCHELLI, propõe o seguinte conceito: "com a expressão compra e venda com exclusividade" se costuma designar, antes de tudo, uma relação da vida social que dá origem a um contrato que (em sentido não técnico, mas lógico ou cronológico) se pode dizer preliminar ou fundamental, e que depois se desenvolve através de repetidos atos que, de per si, e se não fossem pela sua dependência funcional do contrato fundamental, parecem dotados de todos os elementos de fato de outros tantos contratos completos (no caso, o de compra e venda). (in Dal Vecchio al Nuovo Diritto Commerciale, pg. 427).

Aplica-se o contrato de concessão comercial para a venda das mais variadas mercadorias, que necessitam de eficiente comercialização. Encontramos o sistema firmemente arraigado na venda de automóveis ou, mais genericamente, de veículos automotores, de molde a muitos limitarem seus estudos e pesquisas apenas ao contrato de concessão para a revenda de veículos, como ocorreu em seminário patrocinado pelo "Instituto Argentino de Derecho Comercial". Talvez tenha sido, nesse setor, que se tenha iniciado o novo tipo de comercialização de produtos industriais, mas hoje é comum encontrá-los no mercado de eletro-domésticos, de implementos industriais, de distribuição de gasolina, de produtos químicos e até de cosméticos e produtos de beleza. Como vimos na definição de GUYÉNOT, não só empresas industriais dele se valem para o escoamento de suas manufaturas, mas também grandes empresas comerciais, sobretudo importadoras, que também sendo concessionárias exclusivas das empresas estrangeiras, formam redes de empresas revendedoras dos artigos estrangeiros importados. 
4 - Nałureza jurídica - Estabelecida a definição do contrato de concessão de venda com exclusividade, voltamo-nos agora para a elucidação de sua natureza jurídica. Já assentamos que a concessão de venda com exclusividade constitui um negócio jurídico. Surge pelo contrato. A natureza jurídica da nova categoria pode, todavia, ser enfocada também sob o ângulo das empresas, no seu inter-relacionamento. Sob esse prisma notáveis lições tem sido enunciadas pelos juristas modernos, na Europa, que se preocupam seriamente com 0 tema.

Esses estudos avultam de importância devido à defesa que a livre-competição goza nos países europeus, sobretudo em decorrência das disposições do Tratado de Roma, pedra angular das relações entre os países da Comunidade Econômica Européia ou melhor do Mercado Comum Europeu. Nesse relacionamento de empresas, que muitas vezes transcende dos lindes territoriais dos países componentes da Comunidade, surge o monopólio privado, colocando-se assim na zona grigia, entre a economia de mercado livre e a economia monopolística. Por isso fala-se na integração de empresas, chegando uns, como o Professor HOUIN, mais pessimista, a falar em integração vertical, que pressupõe a sujeição de uma empresa a outra mais poderosa, para domínio do mercado. Outros, porém, mais objetivos, compreendem que na organização de uma rede de concessionários, sob a supervisão da empresa concedente, se pretende, efetivamente, a criação de um sistema de serviços pós-venda, em benefício da clientela consumidora e do prestígio da marca da indústria que assinala os produtos vendidos. Na rede de empresas concessionárias com efeito cada uma delas mantém sua independência econômica e autonomia jurídica, pois com o sistema se visa apenas a comercialização da produção, excluindo a imposição de preços e o domínio monopolístico e anti-competitivo do mercado.

O jurista CHAMPAUD, já citado, observa que sendo preservada a autonomia patrimonial e jurídica de cada empresa componente da cadeia, de concessionárias, embora aparentemente, os economistas falam, contudo, em quase-integração (loc. cit. 1963, pg. 460, n. ${ }^{\circ} 10$ ).

Com efeito, são tais os liames que aproximam o concedente do concessionário, que se pode falar, em certos casos, de quase integração. A concedente, por exemplo, abdica de sua função econômica e jurídica no relacionamento com o mercado consumidor de uma produção; exclui a venda direta ao consumidor, interpondo o concessionário revendedor, que se encarrega da comercialização dos produtos que adquire com exclusividade. 
$\mathrm{Na}$ verdade os concessionários abdicam de uma parcela de sua autonomia funcional, pois organizam suas instalações segundo padrões e estilos impostos pelo concedente, que toma a si, muitas vezes, o encargo de especializar os trabalhadores contratados e subordinados ao concessionário. O controle da contabilidade do concessionário, outras vezes, constitui direito do concedente, previsto em cláusula contratual, para verificar o estado dos negócios e a sua estabilidade econômica financeira. Mas se isso, de fato, ocorre do lado do concessionário, não menos verdade é que o concedente também restringe a sua autonomia, pois se compromete a não vender a outrem ou diretamente no mercado os seus produtos, respeitando a área ou zona concedida ao concessionário.

Não se pode negar, é claro, o interrelacionamento das duas empresas, concedente e concessionária. Mas esse interrelacionamento é mais de natureza econômica do que jurídica. Não há integração vertical entre uma empresa e outra, a exemplo do que ocorre nos trustes e cartels. O interrelacionamento das empresas se procede no sentido horizontal, num sistema de quase integração. $O$ sistema configura uma divisão de trabalho, lei econômica universal, que in casu se estabelece pela convenção na qual o concessionário se encarrega da comercialização dos produtos objeto da produção a cargo do concedente.

Sob o estrito senso jurídico, podemos determinar que a concessão de venda com exclusividade constitui um contrato complexo e atípico, de fundo monopolístico, para cuja formulação jurídica se lança mão de vários elementos emprestados a outros contratos típicos. É o que demonstraremos a seguir.

5 - Qualificação do contrato de concessão comercial. - Passamos a analisar o contrato de concessão de venda com exclusividade em face das categorias contratuais conhecidas e já classificadas pelo Direito.

Os juristas não se conciliam sobre a classificação do contrato que nos preocupa. Para uns o contrato é atípico, para outros configura um contrato de coordenação. Há quem o conceitue como contrato de adesão, enquanto para outros se apresenta como espécie nova. Chega-se, ainda, a aproximá-lo do contrato de licença de marca, e não falta quem o lance na vala comum dos contratos sui generis, afrontando a desdenhosa acusação de VIVANTE aos comercialistas que, incapazes de se situarem em face de novas categorias jurídicas, apelam para o cômodo rótulo de "sui generis", descartando-se das dificuldades que não sabem vencer. 
Passamos os olhos sobre o tumulto. No verbete "Exclusiva (clausola di)", da Enciclopedia del Diritto, o jurista BONASI-BENUCCI, após situar o nosso contrato entre os contratos de coordenação, com apoio em artigo de SALANDRA, volta-se para os que o consideram, face evidentemente ao direito italiano, como contrato atípico: "Tendo em vista a natureza desse contrato - escreve o autor - se fala em relação atípica ou de operação complexa, ou de um negócio que reune muitos tipos contratuais (negócio misto), devendo-se nessa última hipótese, resolver o quesito de sua disciplina ou com recurso a combinação das disciplinas dos vários tipos contratuais ou com princípios da observação da parte da disciplina da relação principal" (ob. cit. vol. XV, pg. 383).

Mas o Professor CHAMPAUD, sustenta que esse contrato não é somente um contrato novo, "é uma noção nova". A princípio, diz - Professor de Rennes, é necessário admitir que a situação jurídica das partes é dominada por princípios contraditórios. Duma parte o concessionário conserva aparentemente sua completa independência jurídica e patrimonial; de outra parte sua empresa é economicamente e contratualmente integrada naquela do concedente". A complexidade dessa situação fática se reflete na perplexidade de CHAMPAUD, como a de todos os autores, para classificar entre as categorias jurídicas conhecidas, o contrato de concessão de venda com exclusividade. E aduz: "Com efeito, as hesitações e as controvérsias doutrinárias decorrem da contradição evidente que já foi revelada entre วs elementos característicos das situações jurídicas das partes. Considerando a importância jurídica da venda para revender, efetuada pelo concessionário - prossegue o jurista - alguns têm desejado ver nesse contrato um tipo especial de venda comercial. Conciliando a preponderância permanente das relações comerciais entre as partes, outros tem querido aproximar a concessão de licença da concessão de licença de marca. Impressionados com a dominação econômica e jurídica do concedente, uma opinião sugeriu assimilar o concessionário a um mandatário, e até a um preposto assalariado. Enfim, desconcertados por tantas qualificações possíveis e contraditórias autores tem proposto que, admitindo-se que nenhuma seja perfeitamente exata, é necessário ver na concessão comercial um contrato sui generis" (loc. cit., 1963, pg. 464, n. ${ }^{\circ} 18$ ).

Depois de recusar todas essas classificações, e mais a de que seria uma venda com encargos, ou assimilá-lo ao contrato de fornecimento, o Professor CHAMPAUD se volta para a teoria alemã dos contratos "d'affiliation". E se coloca em face do problema: "Assim, por original que seja, o contrato de concessão não está sem parentes- 
cos. Ele poderia, aliás, ser aproximado de outros contratos tais como o de entente, ou entre essas convenções chamadas de "acordos técnicos" para a prática e que os juristas alemães designam pelo termo genérico de contrat d'affiliation". Todos esses contratos tem por fim concentrar o poder econômico. Não é de admirar que eles saiam da mesma família e apresentem características jurídicas semelhantes. Todavia esse relacionamento não encerra a discussão sobre a natureza jurídica do contrato de concessão comercial, visto que a teoria geral das convenções de concentração está por ser feita" (loc. cit. pg. 470, n. ${ }^{\circ}$ 24).

Na mesma Revue Trimestrielle de Droit Commercial, em proveitoso estudo sobre "Les Agents Commerciaux", o Professor HÉMARD, da Faculdade de Direito de Lille, alude aos concessionários, para distinguí-los dos simples representantes comerciais, explicando que os primeiros "se apresentam então como um comerciante comprando a um fabricante seus produtos que ele revende por sua própria conta e a remuneração que lhe advém não é uma comissão referente a uma atividade de mandatário, mas um lucro proveniente da diferença entre o preço de compra e o preço de revenda. A jurisprudência, prossegue o Professor HÉMARD, rejeita na matéria, a qualificação de mandato de interesse comum, mesmo de mandato ordinário, quando $\circ$ adquirente ignora $\circ$ nome do produtor e trata pessoalmente com o concessionário, mas nós cremos que é preciso analisar o contrato sob o ângulo de uma venda que se aproxima da venda à monopólio. Com efeito, o fabricante se obriga a reservar em um setor territorial determinado a venda de seus veículos a um concessionário que, em contrapartida, se obriga a the vender cada ano o número que the é fixado, em condições determinadas tais que o número de agentes que ele deve utilizar para procurar compradores" (loc. cit. 1959, pg. 573).

Com efeito, o estudo do Professor HEMARD exclui, brilhantemente, a possibilidade de se assimilar o contrato de venda de exclusividade ao contrato de representação comercial, e sua distinção é perfeitamente válida para o direito brasileiro. Entre nós, o contrato de representação comercial se tornou um contrato típico, com o advento da Lei n. ${ }^{\circ} 4.886$, de 1965, pelo qual o representante é um intermediário, que age em nome e por conta da empresa representada, não sendo atingido pelos negócios que agencia, ao passo que o contrato de concessão de venda com exclusividade não está regulado legalmente, constituindo pois um contrato atípico, pelo qual a empresa concessionária compra os produtos da empresa concedente para revender. A representação comercial, como o mandato, podem se in- 
tegrar na figura da concessão de venda, como ainda veremos, mas jamais poderiam ser considerados seus elementos preponderantes, para permitir sua classificação como assimiliado ao contrato de agência ou de representação comercial.

Por outro lado, em obra de preponderante cunho prático, "Étude sur le Contrat de Concession Exclusive" - os advogados BERNARD BUISSON, MIGUEL DE LAGGER e XAVIER TRANDEOU DE MARSAC não avançam muito na conceituação jurídica do novo instituto. Dizem eles que se a concessão comercial toma um aspecto resolutamente progressista, no arcaico e irracional aparelho distributivo da França, não se pode perder de vista que ela engendra monopólios de venda, o que quer dizer fenômenos ambíguos que clamam por uma apreciação normativa (ob. cit., pg. $\mathbf{8}, \mathbf{n} .^{\circ}$ 3). Esses juristas, todavia, ao examinarem de forma global o sistema de vendas por redes de concessionários, vislumbram na concessão comercial o contrato por adesão. "O concedente, dizem eles, divisam geralmente o mercado dos produtos em que se trata de assegurar a distribuição em certo núr mero de zonas, cada zona sendo destinada a um concessionário. $O$ conjunto forma a rede. Esta rede é muitas vezes homogênea, e nesse sentido é um verdadeiro contrato de adesão que o concedente faz subscrever por seus concessionários (cb. cit. pg. 13, n. ${ }^{\circ}$ 9). Aliás, é curioso pois o Professor CHAMPAUD também aludiu ao contrato de adesão para qualificar a concessão comercial de venda, escrevendo elegantemente que "pequenos empresários confrontados com gigantes da indústria automobilística, são colocados ante o dilema de HAMLET, ser concessionário ou não, tal são os termos de sua opção"...

6 - Atipicidade do conîrato. Dessa leve excursão que procedemos na doutrina estrangeira, que sempre inspirou os nossos juristas, podemos aquilatar da complexidade da construção jurídica que os comerciantes engendraram, para formular funcionalmente o novo contrato de comercialização.

Importa-nos saber, no âmbito do moderno direito comercial brasileiro, qual a posição que se deve reservar ao contrato de concessão de venda com exclusividade. Podemos desde já afirmar que o contrato é bilateral e comptativo. Isso resulta do sinalagma que the é inerente, pois existe na verdade uma dependência recíproca das obrigações nele contidas, e, como diria ASCARELLI, para essa espécie de contratos, uma troca de obrigações: a empresa concedente (vendedora) entrega as mercadorias e a empresa concessionária (compradora) paga o preço correspondente, se desejássemos reduzir o contrato à sua expressão mais simples. Mas se o contrato é bilateral e comuła- 
tivo, não podemos enquadrá-lo entre as espécies típicas de contratos existentes e já reconhecidos legislativamente em nosso direito comercial. Impõe-se, portanto, o reconhecimento de que se trata de um contrato atípico, de formulação mista ou complexa.

Os contratos atípicos, como ensina o Professor ORLANDO GOMES, formam-se de elementos novos ou resultantes de fusão de elementos próprios de outros contratos. Entre os contratos atípicos, encontramos duas subespécies: o contrato atípico propriamente dito, o qual se estrutura sem a incorporação de partes pertencentes a tipos diferentes, e o contrato misto que se forma de prestações típicas de outros contratos, ou de elementos mais simples, numa combinação que não está prevista na lei (Contratos, pg. 102).

É fácil, portanto, desvendar que o contrato de concessão de venda com exclusividade pertence ao grupo de contratos atípicos mistos, pois, como veremos, ele não se comporta e não se contém dentro da tipicidade clássica do simples contrato de compra e venda, embora reconheçamos que este possa ser considerado como um suporte inicial de sua construção prática e científica.

Descartamo-nos, energicamente, da possibilidade de enquadrar - contrato de concessão de venda com exclusividade como contrato de adesão. Admitir tal identificação, importaria primeiro na revisão conceitual dos contratos de adesão, pois temos sido acostumados a ouvir dos juristas de tomo que o contrato de adesão se caracteriza pela circunstância de que aquele a quem é proposto não pode deixar de contratar, porque tem necessidade de satisfazer a um interesse que, por outro modo, não poderia ser atendido. Como explica o Professor ORLANDO GOMES, são pressupostos do contrato de adesão "o monopólio de fato ou de direito que uma das partes detém eliminando a concorrência, e a necessidade de contratar da outra parte, que a constrange a realizar o negócio jurídico. Se a situação não se configura desse modo, poderá haver contrato por adesão, jamais contrato de adesão".

Todos bem sabemos, ademais, que no contrato de adesão uma das partes se vê imperiosamente constrangida a realizar o contrato, por não ter outra alternativa de que se possa valer. No contrato de transporte, por estrada de ferro ou rodovia, quando o serviço público é concedido monopolisticamente, como também nos contratos de fornecimento de gás ou de eletricidade, para citar os mais correntios, o contratante nada mais pode fazer do que aderir ao contrato ou não aceitar a prestação. Ora, no sistema de comercialização organizado através do contrato de concessão de venda com exclusividade, a con- 
cedente não tem o monopólio do mercado. A concorrência se estabelece entre várias empresas industriais concedentes, dentro da liberdade do mercado e segundo os termos da livre competição. Quando se fala que o contrato de concessão comercial configura um contrato monopolístico, se usa da expressão no sentido relativo, isto é, monopolístico porque a empresa concessionária é a única ou exclusiva distribuidora ou revendedora de certo produto manufaturado ou importado pela empresa concedente. Além do mais, a empresa concessionária não é constrangida a contratar; ela se dispõe ou se constitui para integrar a rede de revendedores exclusivos de certa empresa, com as quais discute as condições de concessão. É claro que nessa quase integração de empresas, uma, a mais forte, tem poder de impor suas condições, que a mais fraca ou as aceita ou as rejeita, procurando seus interesses então junto a outras competidoras. Mas enquanto outros contratos isso ocorre, quando o contratante mais fraco ou mais necessitado se sujeita às condições impostas pelo mais forte?

Elucidados esses pontos conceituais preliminares, podemos consequentemente afirmar que o contrato de concessão de venda com exclusividade é um contrato de natureza bilateral e comutativo. Não é um contrato típico, constituindo-se, ao contrário, como um contrato atípico, de modalidade mista. O Professor FRANCESCHELLI - qualifica como um contrato comercial, não solene, consensual, definitivo, comutativo, oneroso e bilateral.

7 - Disłinção em relação aos conłratos afins. Afirmamos que - contrato de concessão de vendas com exclusividade constitui um contrato atípico misto, pois se compõe de prestações de natureza diferentes emprestadas de contratos típicos. É, valha-nos a expressão, uma verdadeira simbiose contratual. Para atender aos seus complexos objetivos e interesses, o empresário lança mão de certas prestações típicas oriundas de outros contratos conhecidos, e os funde numa nova e original modalidade.

De todo esse aglomerado de prestações que se justapõe e se harmonizam e se completam no contrato de concessão, avulta sem dúvida, e se sobressai, o contrato de compra e venda. Autores iá pretenderam inutilmente considerá-lo um simples contrato de compra e venda com encargos, o que seria simplificar demais e desconhecer a sua inerente complexidade. Profundas diferenças, com efeito, existem entre o contrato de compra e venda e o contrato de concessão de venda com exclusividade. O mais que poderíamos avançar, seria considerar o contrato típico de compra e venda mercantil como o núcleo inicial, a pedra angular, sobre o qual se edifica 
a disciplina do contrato de concessão de venda com exclusividade, sem desdenhar da valiosa e importante contribuição de outros contratos que compõem o novo esquema negocial.

O Professor REMO FRANCESCHELLI estuda profundamente as diferenças entre os dois contratos, estabelecendo que o contrato de concessão comercial constitui um contrato fundamental, fonte da relação unitária que se instaura entre as partes, de forma a tornar possíveis e devidos os repetidos atos de compra e venda, que dão vida a persistência à relação contratual. Mas adverte o Professor de Milão que "isso não leva a crer que a relação necessite, para seu aperfeiçoamento, da efetivação de um ou mais atos de compra e venda. $\mathrm{Na}$ realidade ela subsiste, como contrato de compra e venda com exclusividade, ainda antes que algum ato de compra e venda seja, na realidade, cumprido. Ele é perfeito e definitivo e obrigatório para as partes, não apenas quando se verifique $o$ in idem pacitum consensus. E logo desse momento ela produz entre as partes recíprocas obrigações de relevo imediato". E encerra seu pensamento nesta visão conclusiva: "O contraîo fundamental, em suma, é um contrato definitivo, essencial, não formal. (Digo, veja-se bem - adverte o jurista iłaliano - tudo isso ocorreu, o contrato está em plena execução e, no entanto, não se procedeu a nenhum contrato de compra e venda entre o concedente e o concessionário)" (Ob. cit. n. ${ }^{\circ}$ 5, pg. 435).

$\mathrm{Na}$ verdade, quando o contrato de concessão de venda com exclusividade se estabelece entre o concedente e o concessionário, aquele se compromete a vender o produto e este a comprá-lo; aquele entregará a cousa e este pagará o preço. Por outro lado, esse mecanismo fundamental e básico, por si só afasta a possibilidade de o nosso contrato ser classificado entre os contratos de mediação ou de intermediação. Nos contratos desse tipo, entre os quais se salienta pela sua modernidade o contrato de agência ou contrato de representação comercial, o agente ou representante não adquire a mercadoria, não a compra, a qual assim não se incorpora em seu patrimônio e não constitui sua propriedade. Ele apenas aproxima as partes, realizando o negócio para outrem. A compra e venda, destarte - se estabelece entre o vendedor e comprador, em consequência de sua aproximação pelo mediador.

Mas, retornando à figura da compra e venda, verificamos que esse tradicional contrato figura entre os que tipicamente se classificam como contrałos de execução instantânea. Logo que as partes, diz - Código Comercial, se acordam na coisa, no preço e nas condições, - contrato é perfeito. A tradição da coisa constitui uma obrigação 
pessoal, já que em nosso sistema jurídico o contrato de compra e venda não configura contrato real. O contrato é, pois, de execução instantânea. Quando o pagamento do preço é diferido, temos nova modalidade de contrato de compra e venda a crédito ou a prestação, no qual as empresas hoje acrescem pacto adjecto de "financiamento ao consumidor". No contrato de concessão de venda com exclusividade verificamos facilmente que ele não configura contrato de execução única ou de execução instantânea, elemento essencial da tipificação da compra e venda. A distinção é flagrante e conclusiva.

Não configurando o contrato de concessão de venda com exclusividade contrato de execução instantânea, mas de execução diferida e contínua, alguns autores foram tentados a identificá-lo com o coniraîo de subministrazione. Se tomarmos a definição que nos é oferecida pelo art. 1.559 do Código Civil italiano - pois falta ao direito brasileiro a sistematização legal do contrato de fornecimento - veremos que "o fornecimento é o contrato pelo qual uma parte se obriga, contra a satisfação de um preço, a realizar, a favor da outra, prestações periódicas ou contínuas de coisas".

Ora, o contrato de concessão de venda com exclusividade não é tão simples assim. Ele toma, não resta dúvida, do contrato de fornecimento também muitos de seus elementos, como o fez do contrato de compra e venda. Mas a diferença é flagrante, pois no contrato de fornecimento as prestações se executam periodicamente, pela tradição contínua de coisas, ao passo que no contrato de concessão comercial o concedente e o concessionário se obrigam a diferentes prestações, muito mais do que o simples pagamento do preço e da tradição periódica de coisas. Aliás, o Professor FRANCESCHELLI contesta a identificação que FERRI pretendeu estabelecer entre a concessão comercial e o fornecimento. Existem diferença, diz ele, sejam de estrutura, sejam de funções. "Do lado da função, de fato, embora consentindo que o fornecimento possa servir a uma multiplicidade de deveres, não se nega que, na normalidade dos casos, e na súa aplicação mais comum e conhecida, esse contrato visa a prover as exigências econômicas de particulares, estabelecimentos ou administrações, consumidores ou consumidoras de determinados materiais e produtos. Na venda com exclusividade, ao contrário, o concessionário não é ele próprio um consumidor dos produtos de que se assegura com a exclusividade. No fornecimento os materiais ou os produtos são comprados em função de sua propriedade orgânica e natural; na compra e venda com exclusividade, em relação a produtos de uma determinada marca. No fornecimento, por isso, o fornecedor pode valer-se de produtos tendo a qualidade requerida ainda que de di- 
versos produtores; na compra e venda com exclusividade, não". Enfim, o fornecimento serve para satisfazer necessidades próprias do comprador, ao passo que a compra e venda com exclusividade visa a fornecer ao concessionário bens para revender ou para dar em locação. (Ob. cit. n. ${ }^{\circ}$ 17. pg. 463).

Como vemos, o contrato de fornecimento é funcionalmente simples, ao passo que o contrato de concessão de venda com exclusividade ao contrário, é evidentemente complexo. O concedente não se limita a entregar, como o fornecedor, a cousa verıdida, mas tamibém se obriga a fornecer as peças de reposição, com as quais o concessionário vai atender à clientela após a venda. Geralmente, além disso, o concedente fornece-lhe os meios de formação técnica de mão de obra. O que interessa, sobretudo ao concedente, ao nomear o seu concessionário, é que este adquirindo as mercadorias se comprometa perante a clientela a assistí-la pós-venda, assegurando, assim, o prestígio da marca.

Não se confunde, também, o contrato de concessão comercial com o contrato de comissão mercantil. Neste o comissário age em seu nome, mas por conta do comitente. É o mandato sem representação. Na concessão comercial o concessionário não age pelo concedente, mas em seu próprio nome, em seu próprio interesse, revendendo o que comprou.

Complica-se, ainda mais, o contrato de concessão de venda com exclusividade, com o acréscimo de elementos de contrato de locação de serviços. Com efeito, quando se estabelece o contrato entre o concedente e o concessionário, nos quais se inclui a prestação de assistência pós-venda a favor dos consumidores, essa relação integrante do contrato configura um contrato de locação de serviço. $O$ problema do prestígio da marca de comércio ou de indústria passa a ser elemento de relevo na intenção do concedente ao formar a rede de seus concessionários. Não importa, veja-se bem, para o concedente, a simples venda de seus produtos no mercado consumidor, a cargo do concessionário. Pretende ele a fixação da clientela, induzida pela excelência dos produtos que sua marca assinada. É imprescindível, para tanto, que o concessionário esteja capacitado tecnicamente a atender os produtos adquiridos pela clientela, após a venda. O "serviço de assistência" que as grandes marcas proporcionam, a "garantia" oferecida para o funcionamento regular ou para a qualidade da mercadoria, quanto mais eficientes e perfeitos evidentemente maior prestígio e preferência the dão. Quando compramos um automóvel, ou quando a dona de casa compra um eletro-doméstico, a primeira cousa 
que se exige é a "garantia" de qualidade e a perfeição do serviço de assistência pós-venda.

O concessionário, assim, se obriga a investir ponderáveis capitais para se aparelhar e para se capacitar a oferecer à clientela a assistência ou manutenção da coisa comprada. Ele se instala, além disso, com estoques de peças, se equipa com máquinas especializadas e, sobretudo, com mão de obra qualificada e de alta tecnicidade. Muitas vezes, quando se trata de equipamentos mais sofisticados e complexos, a concedente assume o encargo de especializar a mão de obra, por meio de estágio do pessoal em suas grandes fábricas e de cursos de formação técnica.

Vemos, por tudo isso, como é complexo o nosso contrato. Nele, no amalgama de prestações típicas que empresta de outros contratos, já identificamos elementos do contrało de compra e venda, do contrato de fornecimento e do conirrato de compra de serviços. Em muitos casos, e autores argutos já verificaram, podemos ainda encontrar elementos do contrato de mandato ou de contrato de empreitada. Com efeito, é comum, ao lado da prestação do serviço de assistência, a concessionária assumir o encargo, como mandatária da concedente, agindo por conta e em nome dela, ao praticar certos atos. Isso ocorre, por exemplo, na substituição de peças defeituosas, fato tão comum na produção em massa. Nesses casos, a concessionária, para executar a prestação de garantia assumida pela concedente, realiza prestação ou de mandato ou de empreitada.

8 - A clausula de exclusividade. Nesta árdua pesquisa sobre o contrato de concessão comercial, deve-se considerar ainda um de seus elementos cuja relevância se integra em seu nomen iuris: a exclusividade. Alguns autores italianos a estudam como cláusula contratual ("clausola di exclusiva" - BONASI-BENUCCI) enquanto outros a vem como um pacto ("pacto di esclusiva"). Para o Professor FRANCES CHELLI e exclusividade age "como poderia funcionar por exemplo a condição, que atua sobre o contrato a que vem aposta, mas não the modifica o tipo".

$\mathrm{Na}$ doutrina que se forma sobre o contrato de concessão comercial se tem sustentado que constitui a exclusividade um elemento acidental em senso técnico e como um elemento natural, do contrato (FRANCESCHELLI, ob. cit. n. ${ }^{\circ}$ 13, pg. 458). É tal a complexidade das relações jurídicas que o contrato engendra, tais são as importantes obrigações que as partes assumem, tantos interesses se formam em torno de sua execução, que é difícil normalmente conceber a concessão comercial sem a condição de exclusividade. 
A cláusula, todavia, não é aproveitada apenas pelo nosso contrato, pois pode acrescer ao contrato de agência, de fornecimento, de locação de serviço, de trabalho e tantos outros.

A exclusividade atua tanto no sentido de favorecer o concessionário, pois se estabelece um relativo monopólio de venda a seu favor, como em benefício do concedente, de vez que ela exclui a sua atividade em relação aos produtos concorrentes. Essas recíprocas obrigações, tanto negativas como positivas, para REMO FRANCESCHELLI são os fundamentos da exclusividade. Assim, resume aquele jurista, no caso de exclusividade a favor do concedente, o concessionário não poderá comprar de outrem, para revendê-los, produtos em concorrência com aqueles objeto do contrato; e, do mesmo modo, no caso de exclusividade a favor do concessionário, o concedente não poderá vender para outrem, na zona reservada ao concessionário, os produtos de que se trata. Mas surgem imediatamente, entre as partes, obrigaçóes positivas de fazer, e talvez ainda de dar. Assim, pelo que diz respeito às obrigações de fazer, o concedente deverá por o concessionário em estado de exercitar sua atividade, e por isso mandar-lhe, segundo a natureza do produto, informações, notícias técnicas, operários especializados etc; e de seu lado o concessionário deverá sair à procura de clientes, fazer publicidade, aparelhar uma sede adequada, contratar colaboradores etc. No que diz respeito às obrigações de dar, a concedente será obrigada a depositar material publicitário, prospectos, objetos de demonstração (p. ex. máquinas), instrumentos, peças de reposição etc. (Ob. cit., n. ${ }^{\circ}$ 5. pg. 435).

É claro, porém, que sendo o concessionário via de regra a parte mais fraca no confronto contratual, a exclusividade é mais imperativa para seus interesses, representando geralmente o segredo de seu sucesso e de seu desenvolvimento empresarial.

Ultimamente se tem verificado uma reação das empresas industriais ao instituto da exclusividade. De fato, a exclusividade é a fonte de inúmeros inconvenientes para o concedente, pois deve ele zelar pela harmonia e disciplina das atividades dos concessionários que formam a rede de distribuição e revenda de seus produtos, a fim de impedir que um invada a área de exclusividade do outro. Por outro lado, o concedente para evitar a queda da atividade da concessionária ou seu acomodamento à rotina, que o monopólio pode acarretar, se reserva a faculdade de nomear mais de um concessionário na mesma área, de forma a estabelecer entre eles, dentro do sistema da concessão, uma sadia competição. A esse tipo de exclusividade pretendemos denominar de exclusividade relariva, con- 
trapondo-a à exclusividade-absoluła, que seria a que assegura ao concessionário o domínio absoluto de sua área, zona ou território sem qualquer outro competidor a serviço do concedente.

Já aludimos aos inconvenientes particulares da exclusividade, mas o Professor GUYÉNOT anotou, mais profundamente, que essa convenção levanta as piores dificuldades porque põe em conflito duas liberdades, aquela de contratar livremente e aquele do comércio, segundo se admita sua validade ou se a interdite. A convenção de exclusividade de venda, prossegue o autor, restringe necessariamente a liberdade do comércio, não somente em obrigando o comerciante a adquirir do concedente os produtos que ele pretende vender à clientela, mas ainda privando os terceiros da possibilidade de se aprovisionarem junto ao produtor ligado a concessionários exclusivos (Ob. cit., pg. 514).

O Professor CHAMPAUD é mais positivo ao revelar o conteúdo monopolístico da convenção: "A exclusividade, diz ele, acordada pelo concedente ao concessionário tem por fim reservar a este último um monopólio de revenda dos produtos do primeiro. As vantagens desse monopólio são diretamente ligadas aos métodos comerciais modernos adaptados à produção em massa e à concentração das empresas" (loc. cit. 1963, pg. 460).

É claro que a exclusividade, aliás como assinalou SAVATIER, engendra certas situações monopolísticas na economia de mercad̄o livre. E exatamente essa circunstância que se choca com os princípios da liberdade de comércio, de que são tão cônscios os comercialistas e empresários. Mas somente em condições de venda com exclusividade, de forma absoluta ou relativa, é que a grande empresa produtora pode organizar e regular a comercialização de seus produtos, zelando pela integridade e prestígio de sua marca. Engendrando monopólios (exclusividade absoluta) ou criando oligopólios (exclusividade relativa), no que diz respeito à comercialização de seus produtos em rede formada pelas empresas concessionárias a indústria moderna se expande, seguindo o princípio universal da divisão do trabalho.

9 - 0 pacto de exclusividade e a recusa de venda. $O$ assunto, como se nota, é polêmico. E assim tem sido tratado, especialmente entre os juristas europeus, particularmente os que se situam em face da Comunidade Econômica Européia, tendo em vista preceitos do Tratado de Roma, que assegura a plena liberdade econômica no Mercado Comum Europeu. 
A ninguém mais o concedente vende que não ao concessionário, por força da cláusula de exclusividade. A exclusão da venda direta do produtor ao comerciante, pois a venda se passa a efetuar com a participação monopolística do concessionário, levou tribunais e juristas franceses a examinarem a questão em face do princípio legal que veda e pune a recusa de venda. A nossa legislação, consubstanciada na Lei de Economia Popular (Lei n. ${ }^{\circ}$ 1.521, de 26-12-1951) também pune severamente, entre outros delitos dessa natureza, o de "recusar individualmente em estabelecimento comercial a prestação de serviços essenciais à subsistência; sonegar mercadoria ou recusar vendê-la a quem esteja em condições de comprar a pronto pagamento".

A dúvida suscitada na França foi objeto de julgamentos contraditórios, tendo afinal propendido o foro francês pela validade da cláusula. O Professor GUYÉNOT equaciona o problema escrevendo que "o contrato de concessão exclusiva comporta a obrigação de recusar a venda aos compradores que não tem a qualidade de concessionários do fornecedor. O problema que se põe é aquele da justificação da recusa de venda oposta a terceiros. A Côrte de Cassação justifica esse efeito da convenção decidindo que ela torna uma mercadoria indisponível em relação a terceiros. No comércio de produtos de alta tecnidade ou de luxo, a Côrte de Cassação ajunta uma outra justificação, em considerando a prática das redes de concessionários exclusivos como um uso do comércio, no sentido do art. $37-1 .{ }^{\circ}$, a, do Decreto de 1958" (Loc. cit. pg. 529).

Tal foi a intensidade da controvérsia, que o Conselho de Estado por fim baixou uma circular - a famosa "Circulaire Fontanet" - disciplinando a matéria, para admitir expressamente a recusa de venda no âmbito da concessão de venda com exclusividade. Nesse particular o Professor CHAMPAUD comenta que "um dos pontos mais vivamente discutidos tem sido o de saber se a proibição editada pelo Decreto de 24 de junho de 1958, se aplicava à recusa de venda emanada de uma concedente. O comentário oficial desse texto, diz ele, a célebre Circular Fontanet o esclarece precisamente, mas essa opinião parece haver estimulado ainda mais as controvérsias do que havề-las apasiguado" (loc. cit., pg. 491).

A Circular Fontanet após várias considerações termina por assentar que, "em definitivo, o contrato de concessão exclusiva não pode constituir uma exceção à interdição de recusa de venda, a não ser que se encontre justificada pelo interesse dos consumidores, se ela é isenta de toda a idéia de fraude dos direitos de terceiros e se 
ela não procede da intenção de limitação voluntária da concorrência condenada pela legislação econômica".

Ora, dessa forma, desde que a exclusividade seja concedida tendo em vista a organização das vendas para proporcionar maior garantia e comodidade aos consumidores, sobretudo no que diz respeito aos serviços de atendimento pós-venda, sendo em suma isenta da idéia de fraudar a liberdade do comércio, é ela legítima. E nesse sentido se tem inclinado os autores e, de forma mais acentuada atualmente, a jurisprudência francesa.

Como é fácil precisar, todas essas consideraçc̃es são válıdas para - direito brasileiro, cuja liberdade de concorrência é assegurada pela lei da economia popular como também pelos dispositivos anti-trusts da lei de repressão ao abuso do poder econômico.

10 - A concessão de venda na legislação comparada. Como vimos estudando, o contrato de venda com exclusividade é construção jurídica moderna, imposta pelas novas necessidades técnicas de comercialização da produção industrial em massa, sendo resultado da inventiva dos empresários. Foram agregadas várias prestações típicas de contratos conhecidos, de modo a se formar nova categoria contratual. Como não podia deixar de ser, já que o fenômeno ocorre no campo do direito comercial, importante papel na construção do novo instituto coube aos usos e costumes.

A nova espécie de contrato logo se impôs, florescendo na sociedade industrial do século XX. Hoje, mercê do notável desenvolvimento industrial do Brasil, o tema começa a preocupar a consciência de nossos juristas. Os estudos entre nós são incipientes, havendo inexpressiva jurisprudência referente à matéria. $O$ mesmo não ocorre em outros países, de há muito tempo industrializados, onde o contrato objeto de nossas preocupações ocupa papel saliente nos estudos comercialistas.

A tal ponto chegou a importância desse instituto, que em torno da concessão de venda com exclusividade se formou notável movimento legislativo em vários países. O legislador, de fato, dificilmente ficaria ausente, em face dos grandes interesses e graves problemas econômicos e sociais que a execução ou não execução do contrato podem acarretar à coletividade. E assim, nas últimas duas décadas, acentua-se o movimento legiferante sobre a matéria.

Na França, o grande líder DELADIER, em 1955, impressionado com os problemas engendrados pela concessão comercial, apresen- 
tou projeto de lei, que infelizmente não teve seguimento. Era a "Proposition de loi n. ${ }^{\circ}$ 480, de 15-2-1955". Desde então se tem reclamado a ação legislativa, tendo o Professor CHAMPAUD considerado que, da falta de normas legais, resulta que "o direito francês da concessão é fragmentário e imperfeito". Informa CHAMPAUD que na Europa a matéria somente é considerada legislativamente na Alemanha e na Bélgica.

Na América encontramos legislação apropriada, de nítido sentido nacionalista, nos países da América Central. Nos Estados Unidos foi surpreendentemente elaborada pelo Congresso uma lei federal de "franquia de marcas de automóveis" (Automobile Dealer Franchise Act), em 1956.

Neste estudo, que agora se volta para a legislação comparada, pretendemos analisar, embora perfunctoriamente, a legislação de alguns países.

Bélgica. Em 27 de julho de 1961, o Parlamento belga promulgou lei relativa à resilição unilaferal das concessões de venda exclusiva de duração indeterminada. O advogado BISEAU DE HAUTEVILLE, de Bruxelas, publicou um opúsculo de larga difusão entre os juristas que estudam o tema, onde reproduz os debates havidos no Parlamento por ocasião da elaboração do diploma legal. E os motivos com que se justifica a elaboração da lei são de tal forma significativos e expressivos que aqui merecem ser reproduzidos: "O legislador se comoveu - escreveu HAUTEVILLE - diante da invasão de nosso país por sociedades estrangeiras que no quadro do mercado Comum vêm estabelecer suas sedes onde antes elas haviam concedido a venda de seus produtos a um concessionário. Muitas vezes esse concessionário havia aplicado, para a finalidade de venda, enormes despesas de publicidade, de locais e de pessoal, e se encontrava inteiramente alijado sem que nenhuma ação pudesse ser intentada por ele contra seu concedente. Este se entrincheirava de ordinário numa argumentação muito simples: ele vendera seus produtos ao concessionário para a revenda; quando do acordo sobre a coisa e sobre o preço de cada produto, a venda fora perfeita. Pouco importavam ao concedente os desembolsos feitos tendo em vista a revenda. Tratava-se de um res inter alios acta. A lei que nos propomos a examinar brevemente, conclui HAUTEVILLE, parece não ser senão um primeiro passo para uma proteção mais extensa" (Le Słatuł des Concessionnaires Exclusifs. pg. 5).

Infelizmente não nos é dado examinar mais a função a monografia belga, mas de muito nos valerá o texto legal. $O$ artigo primei- 
ro, por exemplo, conceitua a empresa concessionária de venda exclusiva como sendo "o comerciante que obtêm de um concedente o direito de vender, a título exclusivo, os artigos ou produtos que esse fabrique ou distribua, e que vende esses artigos e produtos em seu próprio nome e por sua própria conta. O fato de o concedente se reservar o direito de vender ele mesmo diretamente um certo número de artigos ou produtos - esclarece mais o texto legal - não priva o concessionário de sua qualidade de concessionário exclusivo".

Em seguida a lei regula a rescisão do contrato a prazo indeterminado, prevendo que não pode, agora a falta grave cometida por uma das partes no cumprimento de suas obrigações, ser rescindido senão mediante um aviso prévio razoável ou uma justa indenização a ser determinada pelas partes no momento da denúncia do contrato, e na falta desse acordo o juiz decidirá por equidade. Mas se o contrato preceitua o artigo terceiro, for rompido pelo concedente por outros motivos que não por falta grave do concessionário, ou se este põe fim ao contrato em razão de falta grave cometida pe!o concedente, o concessionário pode pretender uma indenização complementar equitativa. Essa indenização é avaliada, conforme o caso, em função dos seguintes elementos:

"1. - a mais valia notável de clientela, conseguida pelo concessionário e que permanecer com o concedente após a resilição do contrato;

2. ${ }^{\circ}$ - as despesas que o concessionário se expôs em vista da exploração do contrato;

3. - as indenizações (multas) que o concessionário deve ao pessoal que ele está na obrigação de despedir em consequência da resilição da concessão de venda. O Juiz decidirá conforme a equidade e levando em consideração os usos".

São esses os preceitos fundamentais da comissão. Os três itens em que se funda a indenização, quando a rescisão contratual foi provocada pela vontade unilateral e desmotivada do concedente, abrangem inteligentemente todo o campo em que se situa o prejuízo provável do concessionário. E é isso, evidentemente, que se pretende esclarecer nos estudos doutrinários dedicados à matéria, nos países que não contam, como o nosso, com proteção adequada ao concessionário, isto é, a indenização da clientela que é absorvida pelo concedente, em vista do prestígio que a marca adquire no mercado consumidor graças, sobretudo, aos esforços do concessionário; as despesas a que se expôs o concessionário, como o de propaganda, se 
for o caso, aparelhamento, especialização de mão de obra e, o que é estudado a fundo pela doutrina francesa, a indenização pelo esto que de peças de reposição, que sem a concessão nada vale em mãos do concessionário demitido; e, por fim, a indenização pelos prejuízos causados pelo pagamento forçado dos direitos relativos aos contratos de trabalho dos empregados demitidos e que estavam dedicados aos objetivos da concessão.

Estados Unidos. O papel destacado que o instituto da concessão de venda com exclusividade assumiu nos Estados Unidos já nos foi revelado pelo estudo do Professor BERLE JR., ao qual nos referimos no início deste trabalho. Mas o Professor da Universidade da Columbia tece outras considerações, abordando os problemas legais, quando observa que "ao que parece, a situação legal dos vínculos estabelecidos é de tal natureza que não assiste ao revendedor direito que possa impor; e seja como fôr, os laços econômicos estabelecidos são de molde, a não convir que se questione. Gerou, entretanto, prossegue 0 autor, a presença desse poder um hábito moderador. A penalidade extrema - o cancelamento do contrato - raramente é invocada pela companhia, excetuados os casos de falência, procedimento extremamente incorreto da parte do revendedor, tentativa de transferência de contrato, ou ocorrências de natureza semelhante. Para os casos que exigem a imposição de penalidades, a General Motors, por exemplo, instituiu uma comissão administrativa de revisão para a qual as acusações poderão ser rebatidas e eventualmente ser provada a injustiça do ato, dispondo a comissão de autoridade para revogar o cancelamento" (ob. cit. pg. 77).

As relações jurídicas eram, segundo aquele autor, frouxas. O "contrato" é cancelável, explica BERLE JR. Algumas companhias aceitam o cancelamento do contrato por simples determinação de qualquer das partes. Outras estipulam o cancelamento mediante aviso prévio de noventa dias. Mas para todos os efeitos, nesse particular, a companhia dispõe de posição soberana. O cancelamento de um contrato importa na perda dos esforços e no dinheiro empregados pelo revendedor na consecução de boa vontade, propaganda, vendas encaminhadas, facilidades de serviço estabelecidas e tudo mais. Caso o cancelamento seja efetuado pela companhia, isto facilmente redundará na paralização do negócio; será dificil conseguir-se uma nova agência. Ao que, entretanto, se antepõe o fato de contarem as companhias, em larga escala, com as suas relações de revenda. O cancelamento de um contrato de revenda gera má vontade dentro de uma comunidade, intimida outros revendedores, e, se empreendido arbitrariamente, influenciará diversamente sobre as vendas. Mesmo as- 
sim, devidamente ponderado, o poder em potencial inegavelmente acha-se do lado da companhia" (ob. cit. p. 76).

Devido a esses fatos é que as grandes empresas, como a General Mołors, procuravam amenizar o seu poderio, com as juntas administrativas de recursos, para rever as decisões de cancelamento tomadas pela gerência. Mas a realidade é que tal sistema parece não ter satisfeito a opinião americana, pois pouco depois de ser dada a lume a importante obra de BERLE JR., em 8 de agosto de 1956, o Congresso americano elaborou uma lei federal regulando a rescisão dos contratos de concessão de venda de automóveis - "Automobile Dealer Franchise Act" - que poderíamos traduzir livremente como "Lei das Concessões dos Comerciantes de Aułomóveis".

Constitui esse diploma uma lei complementar da legislação antitrust dos Estados Unidos, tendo declaradamente em seu preâmbulo justificado sua elaboração "com a finalidade de equilibrar o poder, atualmente muito grande, dos fabricantes de automóveis, permitindo aos concessionários propor ação de indenização nos tribunais distritais dos Estados Unidos, por danos causados em virtude da má fé dos fabricantes no cumprimento dos termos das concessões, ou colocando um fim a elas ou não as renovando".

Essa lei, entre as definições apresentadas na Secção Primeira, item b, conceitua: "O termo "concessão" (franchise) significará o acordo ou contrato escrito, celebrado entre qualquer fabricante de automóveis, dedicado ao comércio e qualquer vendedor ou distribuidor de veículos, que importe na fixação dos direitos e obrigações legais das partes".

Na Secção Il está expresso: “Um comerciante de automóveis pode propor ação contra qualquer fabricante de veículos dedicado ao comércio, em qualquer tribunal distrital dos Estados Unidos no distrito em que o dito fabricante residir, for encontrado ou tiver um agente, independente da quantia em discussão, e será indenizado dos danos sofridos e das custas judiciais, provocados pela má fé do dito fabri-

* Os advogados Beno Suchodolski e J. Jacques Gelman publicaram em secção própria do "O Estado de São Paulo", (edição de 23 de abril de 1972, pg. 40) um artigo intitulado "Sistema de Distribuição em Massa", propondo que o sistema de "franchise" norte-americano fosse introduzido no Brasil para facilitar o favorecimento de pequena e média empresa. Definem o "franchising", baseado em M. Rosenberg, como "um sistema que visa a distribuição seletiva de bens e, ou serviços sob uma determinada marca através de estabelecimentos comerciais de propriedade de comerciantes independentes chamados "franchisees". Da definição e dos demais elementos trazidos pelos referidos articulistas não vemos porque considerar intraduzível para o português a expressão "franchise" do sistema de comercialização norte-americano. Não vemos diferença fundamental entre o sistema descrito e o sistema de concessão comercial, pois neste como já acentuamos se pode visar a difusão e conservação do prestígio da marca. 
cante, a partir da aprovação desta lei e após ela, ao executar qualquer dos termos ou dispositivos da concessão, ou ao por-lhe um fim, cancelá-la ou não renová-la com o referido comerciante. Entende-se que em qualquer ação, o fabricante não será impedido de fazer valer em sua defesa a má fé do comerciante".

Como se vê, a tutela legal norte-americana não pretende, apenas, coibir a rescisão do contrato, mas também atinge a sua não renovação quando consequente de má fé do concedente. Ademais, uma vasta jurisprudência dos tribunais norte-americanos se vem formando em torno da aplicação da lei.

Entretanto, o instituto da concessão (franchise) tem recentemente sofrido profunda transformação naquele país, como se pode observar pela recente revisão de todas as concessões da General Motors. Em novo instrumento de concessão assinado pela General Motors, subsidiária do Brasil, vigorante a partir de $1 .^{\circ}$ de janeiro do corrente ano, o contrato passou a ser por prazo determinado, de cinco anos, ao contrário dos contratos a prazo indeterminado como ocorria anteriormente. A renovação do contrato, vencido o prazo, é automática, por período idêntico, desde que o concessionário não tenha infringido alguma cláusula contratual. A grande novidade, porém, é o abandono da cláusula de exclusividade, que era absoluta. Amenizou-se essa cláusula, pois cessou a proibição de vendas fora da zona ou território marcado ao concessionário.

Cada concessionário da General Motors possui agora o que o concedente chama de "área de responsabilidade". Isso significa que cada concessionário está obrigado a zelar pelo seu território, nada impedindo, todavia, que efetue vendas em áreas de responsabilidade de outros concessionários. O concessionário não pode entretanto, abrir estabelecimento fora de sua área. Mas a General Motors, como concedente, se reserva o direito de dar novas concessões (franchise) em áreas já autorizadas, tendo em vista o potencial de venda da região.

Esse novo sistema é utilizado em todos os países em que atua - GM Overseas, adaptado naturalmente às normas jurídicas respectivas.

Como se vê, a maior empresa industrial dos Estados Unidos se descartou, no sistema de concessões através do qual comercializa sua fabulosa produção industrial, dos percalços que a exclusividade absoluta lhe causava. As constantes invasões de áreas entre os concessionários de sua rede de revendedores, acarretava, como é peculiar ao 
sisteria, graves choques de interesses, para cujo deslinde se invocava a autoridade do concedente, para fazer "as regras do jogo". Estabelerendo apenas áreas de responsabilidacle, ao invés de áreas de exclusividade, esses atritos desaparecem, embora com o enfraquecimento dos direitos do concessionário.

11 - A concessão comercial na América Latina. A legislação de países da América Latina, mais propriamente da América Central, que disciplina a proteção das empresas concessionárias, estão impregnadas, como a lei belga já estudada, de profundo sentido nacionalista. A lei é endereçada claramente contra os abusos de empresas estrangeiras que se radicam no país, rescindindo o contrato com antigas concessionárias, aproveitando-se de sua clientela e do prestígio da marca que elas promoveram.

A extensão deste trabalho não nos permite uma incursão mais profunda no direito comparado dos países latino-americanos, e nos limitamos, por isso, a uma simples notícia dos diversos diplomas que nos vieram às mãos, na pesquisa procedida.

República Dominicana. A intenção de proteção da empresa ne cional, resulta expressa no preâmbulo da lei: "O Estado Dominicano não pode permanecer indiferente ao crescente número de casos em que pessoas físicas ou morais do exterior, sem causa justificada, eliminam seus concessionários ou agentes tão logo estes criaram um mercado favorável na República, e sem levar em conta seus interesses legítimos". Essa lei tem um dispositivo pelo qual o concedente, mesmo tratando-se de contrato no qual as partes se reservem unilateralmente o direito de por fim as suas relações, não poderá dar por terminadas ou resolvidas ditas relações ou negar-se a renovar o contrato em seu vencimento normal, exceto por causa justa.

A consequência dessa regra é, evidentemente, impedir os contratos a prazo determinado, de um ano, ardil que coloca sempre o concessionário sob o guante do concedente, facilmente evitando a prorrogação contratual.

A lei dominicana, enfim, proporciona ao concessionário, no caso de rescisão contratual sem justa causa, o direito de uma "reparação equitativa e completa dos danos e prejuizos que por tal causa the sejam irrogados, cuja quantia se fixará na base de fatores que indica".

República do Panamá. Não fugiu a República panamenha de armar-se também de legislação adequada, afirmando em seu preâmbulo que "é política do Estado panamenho a proteção dos contri- 
buintes no desenvolvimento de suas atividades comerciais, com as quais se obtem a estabilidade econômica e a ordem social". E, considerando, que representantes, agentes e distribuidores autorizados de determinados produtos ou serviços de fabricantes ou firmas nacionais e estrangeiras a quem efetuaram e efetuam constantemente ingentes esforços e gastos para estabelecer o prestígio e a venda efetiva de tais produtos e tem, portanto, o legítimo direito de usufruir o benefício de seus trabalhos, se vem afetados amiúde por resolução unilateral e sem justa causa dos contratos de representação, distribuição ou agência, estabelece a obrigatoriedade de registro do contrato, o qual, rescindindo sem justa causa, deverá proporcionar indenização ao representante, ao agente ou ao distribuidor autorizado.

É claro, como se vê, que a lei panamenha não trata especificamente da concessão de venda, mas é assim compreendida a expressão "distribuidor autorizado" usada pelo referido texto.

Curioso, pela violência do princípio repressivo, é o disposto no artigo 10, pelo qual "nos casos em que se houver produzido a dispensa de um representante, agente e ou distribuidor previamente estabelecido, com infração das disposições do presente Decreto de Gabinete, ficará suspensa a importação ao país do produto ou produtos do fabricante ou firma que haja incorrido na infração, até que o representante, agente ou distribuidor injustamente despedido haja sido restituído em sua condição de representante, agente ou distribuidor, ou o fabricante haja feito os pagamentos completos da indenização estabelecida neste Decreto de Gabinete"...

Honduras. No Decreto n. ${ }^{\circ}$ 50, o Congresso Nacional desse país invoca os problemas que o Mercado Comum Centroamericano, acarreta em relação à representação e distribuição de casas nacionais ou estrangeiras e considera, textualmente, "que muitas empresas estrangeiras que, contando com um mercado seguro para seus produtos em Honduras devido ao paciente labor de seus representantes, cancelam arbitrariamente os contratos de representação ou distribuição que firmaram com eles sem ressarcir de nenhuma forma os danos que esse fato Ihes ocasiona", considera (o Congresso Nacional) necessário ditar normas tendentes a proteger os interesses das entidades dedicadas à representação e distribuição de artigos ou produtos de empresas nacionais ou estrangeiras.

Esclarece $\circ$ artigo $5 .^{\circ}$ que distribuidor é toda a pessoa natural ou jurídica que tem a seu cargo a distribuição, concessão ou representação de determinada mercadoria ou serviço, no país. O artigo 8. dispõe que "nenhum principal ou concedente poderá dar por dis- 
solvida a relação contratual existente com seu distribuidor, tão pouco poderá terminar, modificar ou negar-se a prorrogar seu contrato, sem ocorrer causa devidamente justificada". A indenização pela rescisão do contrato sem causa justificada, ou a não renovação do contrato, obriga a concedente a indenizar o distribuidor "na medida dos danos que lhe causa", cuja quantia se fixará na base de alguns fatores que enumera.

São Salvador. A República salvadorenha afina pelos mesmos princípios. Invocam-se os trabalhos dos agentes-representantes ou distribuidores e de seus direitos de gozar dos benefícios deles resultantes, que "sem embargo vem amiúde afetados por resoluções unilaterais que dão por terminados, sem jusía causa, os respectivos contratos", estabelece uma indenização a ser fixada conforme os fatores que determina.

Argentina. A República Argentina, como ○ Brasil, não possui legislação específica. Em 1970 o Instituto Argentino de Derecho Comercial promoveu um seminário sobre "El Conirrato de Concesion para la Venta de Automotores", de que o ilustre Professor Juan M. Farina, da Faculdade de Direito de Rosário, foi relator. Esse jurista, com nitidez didática, distingue o contrato de concessão do contrato de compra e venda, de agência, de fornecimento, de mandato, invocando literatura estrangeira, pondo em relevo a obra do Professor JEAN GUYÉNOT. Nos debates, após a objetiva explanação daquele Professor, o advogado S. Júlio Rołman afirma que "é inegável que as estruturas clássicas de nenhum maneira são suficientes para distinguir esta classe de convenções e que estas superam as fronteiras dos contratos incorporados em nosso direito (argentino) positivo".

Ao encerrar a reunião de estudos, o Presidente do Instituto Dr. GUILHERMO MICHELSON enfatisou a presença de Comissão de Reforma do Código de Comércio e acentuou que o direito argentino "está reclamando incorporar às suas normas as figuras da agência e da concessão, e seguramente se levarão em conta as informações e conceitos que foram expedidos neste interessante debate" (Conf. "El Contrato de Concesion para la Venda de Automotores Su naturaleza juridica, Instituto Argentino de Direito Comercial, Buenos Aires).

12 - Rescisão do contrato e a indenização. Problemas jurídicos de relevância se colocam agudamente no caso de rescisão do contrato de concessão de venda com exclusividade. Para contornar tais problemas, algumas empresas concedentes procuram desbordá-los não formalizando o contrato por instrumento escrito, nem fixando 
prazo de duração. Dessa forma, supõe que podem a qualquer momento impunemente denunciar o contrato, rescindindo-o sem qual. quer indenização.

Ora, tal concepção não se coaduna perfeitamente com as tendências modernas, que procuram reelaborar a teoria geral dos contratos. A rescisão unilateral desmotivâda pode, perfeitamente, ser revista sob as luzes da teoria do abuso de direito, atribuindo à vítima do ato abusivo um direito à indenização. No caso de rescisão do contrato de concessão de venda com exclusividade, dadas as suas peculiaridades técnicas, podem ocorrer sérias consequências de sua ruptura desmotivada, que o direito não pode e não deve desconhecer.

A jurisprudência francesa se tem preocupado com tais consequências, e a Lei belga de 27 de julho de 1961 classificou-as, como já anotamos, em três categorias de indenização: a) o valor da clientela aportada pelo trabalho do concessionário; b) as despesas feitas pelo concessionário na exploração da concessão e que aproveitam ao concedente após a expiração do contrato; c) as indenizações trabalhistas a que têm direito os empregados do concessionário despedidos em virtude da extinção da concessão. A Lei federal dos Estados Unidos, já analisada, assegura direito à indenização pela ruptura do contrato, sem consideração de prazo contratual, pois terá ela lugar mesmo na hipótese de o contrato a prazo determinado não ser renovado, subordinado evidentemente ao fato de ter a concedente agido de má fé.

Os tribunais franceses, como já anotamos, preocupam-se com as consequências da ruptura contratual, tendo em vista a concessão de aviso prévio, da indenização da clientela e o da indenização do estoque. Parece mesmo serem estes dois últimos tópicos os mais salientes na preocupação dos juristas.

O Professor CHAMPAUD estuda longamente a segunda questão, citando recente decisão da Corte de Paris, na qual se julgou que não é possível admitir que os clientes sejam somente aqueles do concessionário, em matéria de venda de automóveis, pois é evidente que os compradores são clientes tanto do produtor e da marca como, ao mesmo tempo, do concessionário. Essa eventualidade o concessionário devia prever ao assinar um contrato que não comportava nenhu. ma garantia nesse ponto capital, e que constitui contra-partida das vantagens da exclusividade, que resultam da concessão de uma grande marca automobilística (loc. cit. pg. 477). Comenta o jurista que "mesmo quando a jurisprudência admite que a clientela do concessio- 
nário permanece nas mãos do concedente, em caso de não renovação e a fortiori quando ela finge ignorar essa usurpação, a jurisprudência vai então produzir efeitos muitos graves da independência jurídica do vendedor. Este sofre uma espécie de espoliação lícita.

Na Bélgica, segundo HAUTEVILLE, o direito à indenização da clientela proclamada em lei parece se ter inspirado parcialmente na noção do enriquecimento sem causa, com base no artigo 1.382 do Código daquele país. São condições da indenização pela clientela, que a mais valia seja notável (être notable) e permanecer (rester acquise) com a concedente. "É evidente, assinala HAUTEVILLE, que o concessionário - especialmente o vendedor de automóveis - poderá pretender que o concedente verá durante um certo tempo a clientela se fornecer de peças de reposição, mas não é certo que a clientela comprará um outro veículo da mesma marca. Trałar-se-á cada vez de espécies diferentes para as quais os tribunais deverão encontrar solução" (Ob. cit. pg. 32).

Como é fácil verificar, o direito à indenização pela clientela, formada pelo concessionário, constitui matéria de fato, cuja prova resultará do conjunto de circunstâncias que demonstrem se a clientela foi constituída pelo concessionário e não decorre do prestígio da marca ou do concedente.

Quanto ao segundo problema, relativo ao destino do estoque que o concessionário foi obrigado a manter para a reposição de peças na assistência pós-venda, e que não terá mais prestabilidade para - concessionário destituído da concessão, o Professor CHAMPAUD sustenta que a jurisprudência francesa acolhe a obrigação da retomada do estoque pelo concedente, em todas as hipóteses. Explica o professor de Rennes que "quando a concessão diz respeito a bens de equipamento (aparelhos domésticos, utensílios industriais ou agrícolas, veículos, etc.), o contrato prevê geralmente que, desde a sua conclusão, o concessionário compre um estoque de peças de reposição de que assegura constantemente 0 sortimento. A sorte do estoque findo o contrato cria um problema. Vendidos ao concessionário, essas peças mecanicas são de sua propriedade. Uma vez o contrato rescindido, ele não poderá mais escoar este estoque, que pode representar um valor de muitas dezenas, senão muitas centenas de milhares de francos. Algumas vezes o contrato prevê a retomada do estoque ao fim da concessão, mas esta retomada é, às vezes, submetida a condições muito severas relativamente ao prazo durante o qual o ex-concessionário deve pleitear a recompra do estoque. Outras vezes subordinada a obrigação de retomada à ausência de falta do concessio- 
nário que pudesse ter levado o concedente a romper ou a não renovar o contrato; a Côrte de Cassação parece favorável à retomada em todas as hipóteses. Ela tem decidido que devia ser efetuada pelo concedente mesmo nada tendo sido previsto no contrato (loc. cit., pg. 482).

De nossa parte, pensamos que a venda de peças de reposição, em estoque nas mãos do concessionário por imposição do contrato de concessão, constitui uma venda condicional, que depende da permanência da concessão. Cessada esta, sobretudo por iniciativa do concedente, deve ele recompor o estoque e se não o fizer ficará sujeito a indenizar o concessionário pelos prejuizos a que ficar sujeito.

13 - A ruptura do contrato a prazo determinado. Várias legisla ções, já o vimos, não levam em consideração a existência de contrato a prazo determinado, para o efeito de atribuir ao concessionário direito à indenização pela denúncia desmotivada. A lei da República dominicana, por exemplo, veda o direito do concedente de rescindir - contrato mesmo que se reserve o direito expresso de assim agir. "Não pode o concedente dar por terminadas ou resolvidas ditas relações ou negar-se a renovar o contrato em seu vencimento normal, exceto por causa justa", diz o dispositivo legal.

Põe-se, portanto, doutrinariamente a questão da rescisão do contrato a prazo determinado. Como já tivemos ocasião de estudar, em outra oportunidade, no que diz respeito ao contrało de representação comercial (Lir. setembro 1971, pg. 675), a doutrina tradicional de que o termo contratual constitui condição resolutiva e, verificada esta, vencido está o contrato, não resiste às concepções modernas e às necessidades sociais de proteção à parte economicamente fraca. Nesse particular, no que concerne ao contrato de concessão comercial, os autores BUISSON, LAGGER e TRANDEAU de MARSAC, sustentam que "o contrato de duração determinada concluída por um tempo reduzido é de grande voga. Ele é uma arma excelente nas mãos do concedente que não o quer renovar. Com efeito, tem sido muitas vezes julgado que a não renovação do contrato por uma das partes constitui simples exercício de um direito contratual, com exclusão de toda a idéia de abuso de direito (ver, p. ex., Paris, 28 junho 1958, G.P. 1958-2-253)". A recusa contratual, continuam os autores, é um aspecto essencial da liberdade individual: ora, o concessionário é comerciante independente que aceita com conhecimento de causa o risco quando subscreve um contrato de breve duração. É por isso que na indústria de automóveis ou de maquinismo agrícola a regra é a de concluir contrato de duração de um ano, na qual a renovação por tácita recondução é excluida" (Ob. ciț., pg. 52). 
Esse tema está por demais estudado no direito estrangeiro, na parte relativa à teoria da fraude e da simulação. No direito do trabaIho, em vários países inclusive no Brasil, proscrevem-se os contratos de emprego a prazo determinado, admitindo-se em casos restritos excepcionalmente. Na hipótese em estudo, BISEAU DE HAUTEVILLE registra a manobra de se contratar a concessão a prazo determinado com o fim de desbordar o direito à indenização, mas observa que "seria contrário ao espírito da lei admitir que a conclusão do contrato a termos sucessivos, concedentes pudessem iludir a vontade do legislador e impedir aos textos legais toda a sua eficácia", e lembra que já em matéria de contrato de trabalho os tribunais tem usado de rigor contra semelhantes tentativas e decidido que os contratos sucessivos equivalem a uma convenção de duração indeterminada" (ob. cit. pg. 6).

O Professor CHAMPAUD informa que, a respeito do assunto, a jurisprudência francesa está longe de ser fixada, não tendo os tribunais franceses se tranquilizado a respeito. BUISSON, LAGGER e TANDEAU DE MARSAC - registram que "o princípio é que um contrato concluído sem indicação de duração pode ser denunciado a todo o momento por qualquer das partes, sob a reserva somente de não se abusar dessa faculdade com intenção de prejudicar a outra parte ( $\mathrm{Pa}$ ris XV, E. ch. 14-6-61) R. Tr. 1961-1905). O concessionário não tem então nada assegurado em relação à permanência contratual. Ao contrário, rompido o contrato, o concedente se arrisca a ser objeto de uma ação de perdas e danos se, por exemplo, ele não respeita os usos industriais ou comerciais no que diz respeito aos prazos de aviso prévio (Cass. 7 dec. 1960 - R.T. 1961-658).

Vemos, assim, que nos contratos de concessão a prazo determinado as circunstâncias devem indicar se houve abuso de direito na rescisão contratual, para dar lugar ou não à indenização pelos danos sofridos pelo concessionário na não recondução do contrato. Isso deflui, claramente da lei norte-americana, como já vimos.

14 - O tema em face das leis brasileiras. O contrato de concessão comercial de venda se introduziu no direito brasileiro por intermédio de empresas estrangeiras. A experiência, portanto, de outros povos e legislações, repercute intensamente entre nós, tornando imprescindível e útil para o tema a pesquisa no direito comparado. Atualmente, em face de nosso invejável desenvolvimento industrial, as empresas nacionais se tem valido do mesmo processo de comercialização. Integrou-se, portanto, o novo instituto jurídico nas instituições comerciais pátrias. 
Malgrado a importância e assiduidade do contrato de concessão de venda com exclusividade no mercado interno brasileiro, ainda não foi ele estudado sistematicamente sob as luzes de nosso direito comercial. Não temos regras normativas que o disciplinem, e o Projeto de Código de Obrigações dele não tratou. O Projeto, como todos estão lembrados, pretendeu regular apenas o contrato de "agência ou distribuição", com o qual não se pode confundir o contrato de que trałamos. Impõe-se, dada a relevância desse contrato, que seja ele introduzido em nossa legislação, de molde a adquirir tipicidade, disciplinando sua técnica e elucidando suas dúvidas, reduzindo as divergências que já se estão apresentando perante os tribunais.

A jurisprudência é escassa, mas localizamos alguns acórdãos que de contrato de concessão comercial trałaram, embora sem mais expressivo conteúdo doutrinário.

Já no terreno da repressão ao abuso do poder econômico alguma coisa sobre a concessão comercial, com exclusividade, se escreveu. Na monografia "Abusos do Poder Econômico", fruto das pesquisas do Professor BENJAMIM M. SHIEBER, da Universidade de Louisiana, sobre o tema anti-trust no Brasil, examina ele aspectos de legalidade do contrato de revenda com exclusividade. Distingue o Professor Shieber, segundo os modelos jurídicos dos Estados Unidos, a exclusividade imposta pelo concedente, da exclusividade exigida pelo concessionário. No primeiro caso, a imposição de exclusividade da atividade do concessionário a serviço do concedente, por obra deste, importaria em intenções de domínio do mercado, ao passo que lícita seria a exigência de exclusividade por parte do concessionário. Ouçamos a doutrina exposta pelo professor norte-americano: "Portanto, concluímos que acordos para exclusividade de revenda partindo do vendedor devem ser considerados ilícitos quando se trata de uma empresa substancial que não necessita de tais acordos para conseguir uma entrada num mercado". Ora, a situação é diferente quando se trata de acordos de exclusividade para revenda que partem do revendedor". E louvado em depoimento do professor brasileiro KAFKA, que em 1956 depôs perante a Comissão Especial que no Congresso Nacional elaborou a Lei n. ${ }^{\circ} 4.137$, concluia: "A nós parece que as mesmas considerações podem nortear as deliberações do CADE e dos tribunais, ao determinar se um acordo para exclusividade de revenda partindo de um revendedor é lícito, na base dos dispositivos relevantes da lei $n .^{\circ}$ 4.137. Convém notar que na determinação de um acordo que visa ou resulta em dominação dos mercados nacionais, são relevantes as consideraçõos, versando sobre delimitaçżo do mercado que tivemos ensejo de discutir no Capítulo 3, quando aborda- 
mos o problema da Dominação dos Mercados Nacionais e Monopolização. Como exemplo da aplicabilidade destas considerações, podemos apontar um acordo de exclusividade para revenda que concerne só a um produto sob marca quando existem outros produtos que sirvam para a mesma finalidade, não visa dominação de um mercado relevante, visto que um produto sob marca não é um mercado relevante (Ob. cit. pgs. 158/159).

O CADE, órgão criado pela lei citada destinado a reprimir o abuso do poder econômico, tomou conhecimento, em diversos processos, de problemas de comercialização de produtos industriais com cláusula de exclusividade. De grande repercussão foi o julgamento de caso relacionado com a venda de cervejas em que duas grandes empresas industriais dedicadas ao ramo foram acusadas de abuso de poder econômico, e afinal absolvidas. A emenda dessa decisão está vasada nos seguintes têrmos: "A cláusula de preferência, ou mesmo exclusividade, para compra de produtos de uma determinada linha de fabricação, inserta em contrato de comodato, celebrado entre um fabricante e seus respectivos distribuidores ou revendedores, não configura abuso de poder econômico - salvo se a mesma se constituir em meio ou instrumento de agregação de empresas" (Proc. Adm. n. ${ }^{\circ}$, in D.O.U. 10-9-1969).

Sobre o problema da recusa de venda, que surge com a obrigação assumida pelo concedente de vender exclusivamente ao concessionário, negando-se a fazê-lo a terceiros, já foi estudado no n. ${ }^{\circ}$ 9 supra, quando o fizemos examinando a jurisprudência a respeito dos tribunais franceses, invocando inclusive a Lei de Economia Popular (Lei n. $0^{\circ} 1.521$, de 1951). A recusa de venda, com efeito, no caso da concessão, não configura o delito contra a economia popular.

Embora a decisão do CADE não trate de espécie que configure concessão comercial de venda, mas simples contratos de comodato ds utensílios no qual se supunha trazerem em seus bojo cláusulas de exclusividade de venda, firmou a doutrina que interessa a este estudo, quando afirma que a exclusividade é admissível quando não configurar o propósito monopolístico através de agregação de empresas. E assim tem sido entendido, pois se adota a forma de comercialização de produtos industriais através da concessão de venda com exclusividade, sem se por em dúvida a licitude do contrato, que não pressupõe e não importa, como já vimos na doutrina estrangeira na integração vertical de empresas.

Por outro lado, no direito brasileiro o contrato de concessão comercial deve ser visto, segundo nos parece, como um contrato atípico, 
valendo para ele a doutrina estrangeira, sobretudo a que anotamos no direito francês e belga.

Impossível seria, ademais, identificar o contrato de concessão de venda com exclusividade com o de representação comercial, mesmo por analogia, invocando-se a Lei $n .^{\circ} 4.986$, de 1965, que disciplinou o último. Esse diploma legal tutelou os interesses dos que atuam no ramo da representação comercial, agenciando negócios para as empresas representadas. A rescisão desmotivada do contrato importa no pagamento de uma indenização tarifada pela lei, em forma de percentagem sobre as comissões auferidas. Ora, não seria possível invocar-se analogicamente o preceito da indenização tarifada, para a fixação da indenização do concessionário injustiçada com a denúncia unilateral e desmotivada do contrato de concessão, dadas as diferenças radicais já postas em relevo entre um e outro contrato: o representante não compra, nem revende; o concessionário, ao contrário, compra e revende.

Afastada, assim, a possibilidade de identificarem-se os dois contratos, no direito brasileiro, resta estudar o contrato de concessão comercial como um contrato atípico, cujos problemas dele decorrentes devem ser resolvidos segundo as regras gerais do direito obrigacional brasileiro.

Em fase das incertezas que envolvem a nova figura contratual, e seu insuficiente estudo no direito brasileiro, as empresas concedentes, já o dissemos, em geral evitam formular o contrato por escrito. Pensam assim não armar os concessionários com razões e direitos em caso de rescisão abrupta. Além desse temos, a antíga lei do Imposto do Selo, tributo hoje extinto, obrigava, nos contratos escritos, a oposição do imposto de valor elevado, que deveria ser atualizado anualmente conforme o volume efetivo das vendas realizadas. Isso levava as empresas a evitarem os contratos de execução continuada. Sente-se hoje, todavia, como já registramos, um movimento de formalização do contrato por escrito, no qual as normas da concessão são reduzidas a cláusulas, embora tal movimento procure atenuar a gravidade dos efeitos da cláusula de exclusividade.

$\mathrm{Na}$ falta de uma disciplina legal para o contrato, temos de nos valer, no direito brasileiro, da doutrina dos países mais desenvolvidos, resolvendo assim as pendências que surgem no campo da interpretação e aplicação das normas do contrato.

15 - Rescisão do contrato atípico no direito brasileiro. $\bigcirc$ mais sério problema jurídico que enfrentamos, neste terreno, é a deter- 
minação das normas jurídicas que devem ser invocadas para o tratamento das questões resultantes do contrato de concessão. Já verificamos que sendo o contrato de concessão comercial atípico, não constando do elenco dos contratos previstos na lei brasileira, surge ele, da justaposição de regras e prestações tomadas de outros contratos típicos, entre os quais o contrato de compra e venda mercantil, o mandało mercantil, a comissão mercantil, a locação de serviços, a licença de marca de indústria, a empreitada, podendo incluir-se ainda o contrato de publicidade e propaganda, além do contrato de fornecimenło. Essa simbiose ou amálgama de contratos pode ser criada pela conveniência das partes, pois como ensina HEDEMANN, Professor da Universidade de Berlim, as partes tem a liberdade de criar, através de convenção, figuras completamente novas, isto é, tipos contratuais nos quais o legislador não pensou sequer. (Tratado de Derecho Civil, vol. pg. 234).

Para o tratamento jurídico desses contratos, segundo HEDEMANN, se oferecem tres teorias, ou possibilidades, como as chama: a primeira - o sistema da absorção - pela qual uma das partes integrantes do contrato é valorizada como a essencial e absorve as demais; a segunda - sisłema da combinação - importa em que as várias partes integrantes do negócio são tratadas em forma equivalente, e para cada uma entram em consideração as normas especiais correspondentes; a terceira - sistema da emancipação - considera a mescla como criadora de um novo contrato. Em lugar de levantar um edifício misto feito com os antigos fragmentos, se leva a cabo uma nova construção. Essa direção se libera de ter que regular o caso concreto por um dos tipos legais já existentes.

Como não existe legislação específica em nosso direito, e como não pode o juiz deixar de decidir as causas que lhe são apresentadas a pretexto de inexistência de norma legal, estamos em face - na rescisão desmotivada e unilateral do contrato de concessão de venda com exclusividade - de caso de construção pretoriana, na qual os juizes hão de optar por um dos tres sistemas para o deslinde dos problemas emergentes com o não cumprimento do contrato ou a sua ruptura unilateral abusiva. Dos tres sistemas catalogados pelo Professor HEDERMANN optaríamos, de nossa parte, pelo ultimo, ou seja pelo sistema da emancipação.

Ora, se admitirmos, que seja o contrato de concessão de venda com exclusividade uma nova construção de negócio jurídico, independente das origens das prestações contratuais tomadas ou emprestadas de contratos típicos conhecidos, dando-lhe uma interpretação di- 
ferente desamarrada de suas fontes, teríamos que lhe dar um tratamento emancipado, como novo instituto jurídico que é. Não seria válido, portanto, invocar as regras do contrato de compra e venda para para deslindar as questões decorrentes de nova espécie contratual, como por igual não se deveria tomar as regras do mandato ou da locação de serviços ou do fornecimento, para se medir as divergências contratuais. Deve-se, isto sim, partindo das regras gerais de interpretação dos contratos, levando em consideração a técnica empregada na sua construção, tendo em vista a sua natureza, encontrar a melhor solução, segundo os princípios da equidade e da ética que devem presidir as relações de comércio, a boa fé, os costumes, a intenção das partes e, sobretudo, a finalidade social e econômica do contrato. Alıás essa parece a tendência de nossos tribunais em decisão inserida na Revista dos Tribunais, Volume 268, pg. 338, da 6." Câmara Civil, do T. J. de S. Paulo, na ap. civil 81.119, na qual se recomendou que "tratando-se de um contrato complexo ou misto, resultante da combinação de dois tipos de contrato, não se poderá aplicar as regras de um só deles, mas deve-se atender à finalidade essencial da operação". Cresce, enirretanto, de vulto o interesse pelo conhecimento das soluções admitidas pela legislação ou doutrina comparada, trazida da experiência de países mais desenvolvidos, que encontraram, como o nosso, na concessão comercial um eficiente meio de comercialização da produção das empresas industriais. Esses países, cuja teoria jurídica e cuja doutrina sempre inspiraram os nossos juristas e os nossos tribunais, por serem consentâneas com os fundamentos políticos, sociológicos e filosóficos de nosso direito, continuarão a nos inspirar no desenlace das questões ocorrentes na aplicação do contrato.

Examinemos, portanto, as teses básicas surgidas no momento da rescisão dos contratos, tendo em vista o material colhido na pesquisa efetuada no direito comparado. Em primeiro lugar, em face da ruptura do contrato, por qualquer das partes, há de se indagar, segundo a teoria de JESSERAND, do abuso de direito, se tal atitude constitui o exercício regular de um direito e não está marcado por um desvio de sua finalidade de forma a constituir um ato abusivo. É claro que se não houve motivo para a rescisão, seja de que parte for, a rescisão abusiva importará no direito de a parte prejudicada e ofendida plei tear a indenização de perdas e danos, para compor os prejuízos sofridos. A rescisão motivada, obviamente, não enseja, como em qualquer outra hipótese obrigacional, o direito à indenização.

Assentado o direito à indenização das perdas e danos, cumpre indagar quais os elementos que devem identificá-lo para proporcionar o volume da indenização. 
Na doutrina e jurisprudência francesa, bem como na legislação belga, já haviamos destacado adequadas e justas soluções. Delas nos valemos agcra, para aclimatá-las ao nosso ambiente jurídico.

Vejamos, em primeiro lugar, o problema da indenização da clienrela. Já assentamos, segundo as observações dos mestres franceses e belgas, que o problema da indenização da clientela, na ruptura do contrato de concessão comercial, constitui uma questão de fato, que deve ser examinada corretamente em face das pecualiaridades de cada espécie. A indenização, sempre que a clientela é constituida ou ampliada pelo concessionário, deve ser devida pelo concedente que rompeu indevidamente o contrato. Nas mais das vezes, porém, a formação da clientela não se deve aos esforços do concessionário, mas resulta de árduo trabalho do concedente, que pela excelência de sua organização e qualidade de seus produtos, projetou a imagem de sua marca no conhecimento dos consumidores, tornados clientes costumeiros. Se a participação do concessionário nessa formação for insignificante, nada há a discutir. A marca, como acentua BUISSON, pode ser fator de maior atração do que o trabalho do concessionário. E CHAMPAUD observa, com razão, que em certos setores da atividade comercial, sobretudo no que concerne à venda de automóveis, a clientela a mais ligada à marca do concedente do que à pessoa do concessionário. Isso, insiste o professor francês, é notoriamente verdadeiro no domínio dos automóveis. Ora, concluiu o autor, é precisamente sobre esse argumento que certas decisões fundam sua recusa de abonar uma indenização de clientela (Loc. cir̆., pg. 33).

Em nosso país, evidentemente, a indenização seria concedida se - concessionário provasse cabalmente sua participação no aliciamento da clientela, e que a mesma seria mantida pelo concedente em seu proveito, posteriormente à rupiura do contrato.

Em segundo lugar, poderíamos colocar o problema da indenização relativa às despesas de instalação efetuadas pelo concessionário em decorrência do contrato de concessão, para se aparelhar tendo em vista o atendimento dos consumidores. Sem dúvida, a nosso ver, a indenização deve socorrer o concessionário, que ficará com as suas instalações altamente depreciadas, sobretudo quando for constrangido a mudar de ramo comercial. As despesas de instalação, note-se bem, para serem indenizadas devem decorrer do deferimento do contrato de concessão, visto que para as instalações preexistentes não seria lícito cogitar de indenização.

Em terceiro lugar, devemos considerar o grave problema do destino do estoque, posteriormente à época da rescisão contratual. No 
contrato de concessão comercial, quando as partes estipulam a disciplinam o serviço de assistência pós-venda à clientela, o concessionário se obriga a manter estoque de peças de reposição e o concedente a supri-lo dessas peças. No rompimento do contrato sem justa causa, por parte do concedente, é claro que o direito é invocado para delerminar indenização e o destino desse estoque. Na França, como vimos, os tribunais franceses decidem pela obrigação de retomada do estoque de peças por parte da concedente responsável pela ruptura contratual. Esse estoque de pouco vale nas mãos da ex-concessionária; no mínimo sofrerá ponderável depreciação, por perder utilidade em seu poder, ou parte dela, já que o concessionário não tem mais o poder de assistir à clientela, em nome e sob o prestígio da marca do concedente. O fundamento desse direito, a nosso ver, e já o expusemos anteriormente, decorre de ter a venda do estoque sido condicionada à concessão. Rompido o contrato, resolve-se a venda, determinando-se que o concedente ou retome o estoque ou indenize sua depreciação.

E, por último, devemos enfrentar o mais grave dos problemas: o destino dos contratos de trabalho dos empregados do concessionário, destacados para os serviços de atendimento pós-venda. $O$ concessionário, ao se instalar ou assumir os serviços decorrentes da concessão comercial, teve que se aparelhar com pessoal, especializado ou não, e material para atender aos consumidores. Rompido o contrato de concessão comercial, tais empregados serão consequentemente despedidos do serviço do concessionário. A vinculação empregatícia, sem dúvida, se estabeleceu com o concessionário; a este, portanto, cabe - pagamento da indenização traba'hista, decorrente da rescisão dos contratos de trabalho.

O prejuízo decorrente da rescisão das relações de emprego hoje minimizado em parte pelo sistema do "Fundo de Garantia por Tempo de Serviço" - suportado pelo concessionário, deve todavia ser, po:teriormente, composto para indenização devida pelo concedente. Evidentemente, quem provocou a despedida em massa dos empregados do concessionário foi a concedente, que deve, portanto, indenizar os danos sofridos nesse setor.

Muito mais poderia ser dito a propósito do contrato de concessão de venda com exclusividade, sua execução e rescisão. A.s questões focalizadas já bastam, a nosso sentir, para atrair a atenção dos juristas nacionais para o relevante contrato que se vai amiudando em nosso País, em decorrência do acelerado processo de industrialização que assistimos. Outros hão de vir, mais capacitados, para estudar a

Dunals LIaA., J. raulu, iтuv.

TRATADO DE DERECHO CIVIL, J. W. HEDEMANN, Editorial Revista de Derecho Privado, Madrid, 1958.

REPRESENTAÇÃO COMERCIAL - CONTRATO A PRAZO DETERMINADO REITERADAMENTE PRORROGADO - RUBENS REQUIÃO, LTR LEGISLAÇÃO DO TRABALHO, S. Paulo, Setembro de 1971. 